\title{
PEMBELAJARAN STRUKTUR KALIMAT DENGAN METODE KOOPERATIF MODEL TUTOR SEBAYA DI SEKOLAH DASAR
}

\author{
Suwardi ${ }^{1}$, Mukti Widayati ${ }^{2}$ \\ ${ }^{1}$ Sekolah Dasar Negeri Bendungan I, ${ }^{2}$ Program Studi Pendidikan dan Sastra Indonesia \\ Universitas Veteran Bangun Nusantara Sukoharjo \\ AuthorCorrespondence : mukti.widayati@yahoo.co.id
}

\begin{abstract}
The purpose of the research Learning sentence structure in State Primary School Bendungan 1 Subdistrict Kedawung Sragen to: (1) describe the planning of learning sentence structure with cooperative peer tutor model method in State Primary School Bendungan 1; (2) describe the implementation of learning sentence structure with the cooperative model of peer tutors in State Primary School Bendungan 1; (3) describe the obstacles in learning sentence structure with the cooperative model of peer tutors in State Primary School Bendungan 1; and (4) describe the solution constraints learning sentence structure with the cooperative model of peer tutors in State Primary School Bendungan 1. This research is a descriptive qualitative research. The subject of this research is the head of the school, the teachers and students of the State Primary School Bendungan 1. Data obtained using observation, interviews, and analysis of documents. The validity of the data is performed using the triangulation of the data. Data analysis was done using interactive analysis. The results showed that: (1) Learning sentence structure with the cooperative model of peer tutors in State Primary School Bendungan 1. beginning with open lessons, do apersepsi, held a question and answer, and deliver learning objectives. (2) Learning is done by dividing students into small groups. Each group gets a text sentence structure to be discussed. The teacher explains how to write a sentence structure by giving an example in front of the class. The teacher also gives the opportunity to the students to present their work in front of the class. Teachers close the lesson by giving her the motivation to students. (3) the obstacles that appear in learning sentence structure in State Primary School Bendungan 1: Ego students still high, students are still reluctant to observe the sruktur sentences, and Students still trouble memorizing sentence structure. (4) the teacher's Effort in overcoming barriers in learning sentence structure in State Primary School Bendungan 1, namely: the teacher awaken students to dare to perform in front of the class, give understanding and comprehension on the importance of collaboration in writing sentence structure, the teacher pointed to students, but not forcing it, and teachers lead students to pronounce a sentence properly.
\end{abstract}

Keywords: Learning Sentence Structure, Method of Cooperative.

\section{PENDAHULUAN}

Pelaksanaan pembelajaran mata pelajaran Bahasa Indonesia di Sekolah Dasar (SD) pada umumnya sering mengalami kesulitan. Kesulitan siswa Sekolah Dasar (SD) misalnya menemukan kalimat utama dalam paragraf. Pada umumnya guru hanya menyuruh siswa membaca untuk menemukan kalimat utama, tetapi tidak memberikan teknik atau cara lain agar siswa dapat menemukan kalimat utama dengan baik dan benar.

Model tutor sebaya merupakan jenis metode pembelajaran kooperatif yang dirancang untuk mempengaruhi pola interaksi siswa. Model yang dimaksudkan sebagai altenatif pengganti terhadap struktur kelas tradisional. Struktur ini menghendaki siswa saling membantu dalam kelompok kecil (3-5 siswa) dan lebih diartikan pda kerja kooperatif daripada kerja individu. Model tutor sebaya memberikan siswa waktu lebih banyak berpikir menjawab dan saling membantu satu sama lain. Pendekatan pembelajaran dengan metode kooperatif dapat memberikan keuntungan bagi siswa untuk dapat bekerja sama menyelesaikan tugas-tugas akademik dengan teman sebaya, yang 
membutuhkan pemikiran lebih mendalam tentang hubungan ide-ide yang terdapat dalam materi tertentu.

Siswa di dalam menjawab soal-soal yang berkaitan dengan menemukan kalimat utama pada tiap paragraf melalui membaca intensif masih banyak yang mendapatkan nilai di bawah rata-rata. Siswa kurang dapat memahami dan menganalisis soal berdasarkan struktur kalimat dan letak kalimat utama. Di samping itu, siswa cenderung tidak memperhatikan penjelasan guru, banyak siswa yang gaduh, bercanda dengan teman sebangku, dan konsentrasi tidak terfokus, sehingga siswa kurang dapat memahami penjelasan guru.

Oleh Karena itu, sebagai upaya jalan keluar diajukan strategi pembelajaran yang menawarkan suatu model baru. Adapun metode yang ditawarkan oleh penulis adalah model tutor sebaya, dengan mengadakan penelitian dengan judul: "Pembelajaran Struktur Kalimat dengan Metode Kooperatif Model Tutor Sebaya di Sekolah Dasar Negeri Bendungan I Kecamatan Kedawung Kabupaten Sragen".

Penelitian ini bertujuan: (1) mendeskripsikan perencanaan pembelajaran struktur kalimat dengan metode kooperatif model tutor sebaya di Sekolah Dasar Negeri Bendungan I Kecamatan Kedawung Kabupaten Sragen; (2) mendeskripsikan pelaksanaan pembelajaran struktur kalimat dengan metode kooperatif model tutor sebaya di Sekolah Dasar Negeri Bendungan I Kecamatan Kedawung Kabupaten Sragen; mendeskripsikan kendala dalam pembelajaran dalam pembelajaran struktur kalimat dengan metode kooperatif model tutor sebaya di Sekolah Dasar Negeri Bendungan I Kecamatan Kedawung Kabupaten Sragen; dan (4) mendeskripsikan solusi guru dalam pembelajaran struktur kalimat dengan metode kooperatif model tutor sebaya di Sekolah Dasar Negeri Bendungan I Kecamatan Kedawung Kabupaten Sragen.

Pembelajaran merupakan suatu sistem, yang terdiri atas berbagai komponen yang saling berhubungan satu dengan yang lain. Komponen tersebut meliputi: tujuan, materi, metode dan evaluasi. Keempat komponen pembelajaran tersebut harus diperhatikan oleh guru dalam memilih dan menentukan model-model pembelajaran apa yang akan digunakan dalam kegiatan pembelajaran (Rusman, 2011:1).

Pembelajaran struktur adalah salah satu aspek pembelajaran yang harus dikuasai oleh penutur. Materi pembelajaran struktur antara lain struktur kata, bentuk-bentuk kata, cara pembentukan kata, susunan kata dalam klausa dan kalimat. Dalam pembelajaran struktur kalimat, siswa harus diberi kesempatan luas untuk berlatih menggunakan struktur itu. Mereka harus diberi kesempatan luas bagaimana menggunakan bahasa. Pemahaman struktur dasar bahasa Indonesia sangat penting. Pemahaman ini sangat membantu siswa dalam menyusun dan memahami kata, frasa, dan kalimat. Melalui pembelajaran struktur kalimat, guru mengarahkan siswanya agar dapat menerapkan struktur bahasa tersebut dalam penggunaan bahasa sebagai alat komunikasi.

Dasar pemikiran tentang tutorial adalah murid yang pandai memberikan bantuan belajar kepada murid yang kurang pandai. Bantuan tersebut dapat dilakukan kepada teman-teman sekelasnya di sekolah atau di luar sekolah/di luar jam mata pelajaran (Semiawan, 1985:94). Pendapat yang lebih rinci disampaikan oleh Ahmadi (1997:73), yang berpendapat bahwa tutorial adalah bimbingan pembelajaran dalam bentuk pemberian bimbingan, bantuan, petunjuk / arahan dan motivasi agar para siswa belajar secara efisien dan efektif.

Tutor sebaya adalah sekelompok siswa yang telah tuntas terhadap bahan pelajaran, memberikan bantuan kepada siswa yang mengalami kesulitan dalam memahami bahan pelajaran yang dipelajarinya (Suherman, dkk. 2003). Bantuan belajar 
oleh teman sebaya dapat menghilangkan kecanggungan. Bahasa teman sebaya lebih mudah dipahami, selain itu dengan teman sebaya tidak ada rasa enggan, rendah diri, malu, dan sebagainya, sehingga diharapkan siswa yang kurang paham tidak segan-segan untuk mengungkapkan kesulitan-kesulitan yang dihadapinya (Sukmadinata, 2007).

Metode pembelajaran model tutor sebaya adalah pembelajaran yang pelaksanaannya dengan membagi kelas dalam kelompok-kelompok kecil, yang sumber belajarnya bukan hanya guru melainkan juga teman sebaya yang pandai dan cepat dalam menguasai suatu materi tertentu. Dalam pembelajaran ini, siswa yang menjadi tutor hendaknya mempunyai kemampuan yang lebih tinggi dibandingkan dengan teman lainnya, sehingga pada saat dia memberikan bimbingan ia sudah dapat menguasai bahan yang akan disampaikan.

Metode pembelajaran model tutor sebaya dalam kelompok kecil sangat cocok digunakan dalam pembelajaran bahasa Indonesia dan dapat meningkatkan hasil belajar siswa sehingga siswa menjadi lebih aktif dalam mengikuti kegiatan belajar mengajar dikelas dan siswa menjadi terampil dan berani mengemukakan pendapatnya dalam proses pembelajaran. Metode pembelajaran model tutor sebaya dalam kelompok kecil dapat meningkatkan hasil belajar siswa dimana semua siswa aktif, siswa sangat antusias dalam melaksanakan tugas, semua perwakilan kelompok berani mengerjakan tugas didepan kelas, siswa berani bertanya dan respon siswa yang diajar sangat tinggi.

\section{METODE PENELITIAN}

Penelitian ini menggunakan metode kualitatif yang berupa studi kasus. Penelitian dengan jenis studi kasus adalah penelitian yang menjelaskan atau mendeskripsikan secara rinci tentang keadaan sosial suatu unit tertentu. Penelitian studi kasus akan mencari jawaban atas pertanyaan mengapa dan bagaimana, sehingga akan diperoleh jawaban tentang keadaan suatu fenomena yang memunculkan suatu permasalahan.

Strategi digunakan dalam penelitian ini adalah penelitian terpancang (embedded research). Peneliti sudah menentukan terlebih dahulu focus daripada variabel tertentu, akan tetapi dalam hal ini peneliti tetap tidak melepaskan variabel fokusnya (pilihannya) dari sifat yang holistik sehingga bagian-bagian dari konteks secara keseluruhan guna menemukan makna yang lengkap. Penelitian tersebut dilakukan hanya satu tempat yaitu Sekolah Dasar Negeri Bendungan I. Dikatakan terpancang karena fokus utama penelitian telah ditentukan sejak awal sebelum ke lapangan. Sejak awal, masalah telah dirumuskan untuk membimbing arah penelitian.

Teknik pengumpulan data dalam penelitian ini adalah: (1) Pengamatan langsung yaitu kegiatan memperhatikan atau mengamati keadaan suatu objek penelitian, yaitu peristiwa pembelajaran, secara langsung. Pengamatan langsung dalam penelitian ini menghasilkan data berupa catatan-catatan yang berhubungan dengan proses pembelajaran mengenai aktivitas guru baik gerakan dan ucapan maupun siswa, situasi kelas, atau kejadian-kejadian dalam kelas yang sedang diamati; (2) Dokumen adalah naskah/arsip/informasi yang disimpan sebagai bukti otentik. Pengumpulan data yang bersumber pada dokumen diperoleh dari lembaga atau dokumen seseorang yang terkait dengan permasalahan penelitian. Dokumen yang berkaitan dengan masalah penelitian ini antara lain:daftar nilai siswa, data administrasi kelas, dan catatan guru; (3) Wawancara atau interview adalah pengumpulan data melalui tanya jawab dengan nara sumber yang dapat memberikan informasi tentang permasalahan yang dikaji. Wawancara dilakukan 
dengan guru kelas $\mathrm{V}$ dan siswa kelas $\mathrm{V}$. Wawancara dengan guru bertujuan untuk mengetahui sejauh mana persiapan pembelajaran, pelaksanaan kegiatan pembelajaran, yang meliputi sumber belajar yang digunakan, kesulitan-kesulitan yang dihadapi guru dalam proses pembelajaran dan cara-cara mengatasi kesulitan tersebut. Wawancara kepada siswa kelas $\mathrm{V}$ bertujuan untuk mengetahui pendapat siswa tentang guru yang mengajar, penjelasan guru, dan hasil pembelajaran.

Model analisis yang digunakan dalam penelitian ini adalah analisis interaktif dari Milles dan Huberman. Yaitu: Pertama reduksi data adalah merupakan proses pemilihan data, penyederhanaan data, pengabstrakan dan transformasi data mentah yang diperoleh dari catatan-catatan tertulis di lapangan. Kedua penyajian data adalah merupakan pengumpulan informasi secara sistematis yang mengarahkan pada penarikan kesimpulan. Ketiga adalah penarikan simpulan atau verifikasi adalah sebenarnya sudah dilakukan sejak pengumpulan data, yaitu dengan mencatat dan memberi makna terhadap sesuatu atau peristiwa yang terjadi (Milles dan Huberman, dalam Nugrahani, 2010).

\section{HASIL PENELITIAN DAN PEMBAHASAN}

Guru sebelum pembelajaran terlebih dahulu menyusun perangkat pembelajaran yang meliputi silabus, program tahunan, program semester, rencana pelaksanaan pembelajaran. Silabus meliputi: standar kompetensi, kompetensi dasar, materi pokok, kegiatan Pembelajaran, indikator, penilaian, alokasi waktu dan sumber bahan. Penentuan alokasi waktu ditentukan pada jumlah jam pelajaran sesuai dengan struktur kurikulum yang berlaku serta keluasan materi yang harus dikuasai oleh murid.

Prota dan Promes menentukan keberhasilan karena dengan alokasi waktu yang sesuai dengan KD maka pembelajaran akan sesuai yang di rencanakan. Rencana penetapan alokasi waktu satu tahun untuk mencapai tujuan (SK dan KD) yang telah ditetapkan. Satu semester terdiri dari 19 minggu kerja termasuk penyelenggaraan tatap muka, ujian tengah semester dan ujian semester.

Rencana Pelaksanaan Pembelajaran (RPP) pada haketatnya merupakan perencanaan jangka pendek untuk memperkirakan atau memproyeksikan apa yang akan dilakukan dalam pembelajaran. Dengan demikian, RPP merupakan upaya untuk memperkirakan tindakan yang akan dilakukan dalam kegiatan pembelajaran.

Guru mengawali pembelajaran dengan salam, kemudian melakukan presensi. Guru mengkondisikan kelas untuk mengecek apakah siswa sudah siap untuk mengikuti proses pembelajaran. Guru memberikan motivasi sebelum memulai pelajaran. Siswa memperlihatkan perhatian mereka kepada setiap kalimat yang guru ucapkan. Guru melakukan tanya jawab sebagai apersepsi. Guru mendemonstrasikan cara penyusunan struktur kalimat. Siswa diberi kesempatan untuk menanyakan hal-hal yang mereka rasa belum jelas. Pada awalnya tidak ada siswa yang mau bertanya, namun akhirnya guru memberikan beberapa pertanyaan secara bergilir dan apabila siswa tidak dapat menjawab maka akan dilemparkan ke siswa yang lain.

Guru menjelaskan tentang pembelajaran kooperatif model tutor sebaya. Guru menetapkan siswa ke dalam kelompok-kelompok belajar kecil secara heterogen dengan tutor sebagai ketuanya, yang memiliki nilai prestasi belajar di atas rata-rata. Langkahlangkah dalam pembagian siswa kedalam kelompok adalah menentukan jumlah kelompok tiap kelompok terdiri dari empat anggota. Siswa dikelompokkan kedalam 8 kelompok tiap kelompok empat siswa, dengan 1 siswa sebagai tutor atau ketua kelompok 
yang memiliki nilai prestasi belajar diatas rata-rata. Membagi siswa ke dalam kelompok tiap kelompok terdiri dari siswa yang berprestasi rendah, sedang, dan tinggi.

Guru meminta tutor dari tiap kelompok untuk maju ke depan kelas untuk mendapatkan penjelasan materi, arahan, dan petunjuk cara pengerjaan soal diskusi sebagai pedoman kegiatan tutorial berlangsung. Selama belajar dalam kelompok, tugas tutor dalam kelompok adalah menguasai materi pelajaran dan membantu teman satu kelompok untuk menguasai materi. Anggota kelompok yang mengalami kesulitan terlebih dahulu bertanya kepada teman sekelompok, tutor sebaya, dan apabila mengalami kesulitan baru bertanya kepada guru.

Guru memberikan sedikit motivasi agar mereka berani tampil ke depan. Selama presentasi, keempat anggota kelompok aktif mempresentasikan hasil kerja kelompoknya. Guru mengawasi jalannya presentasi sambil berkeliling dan membuka kegiatan diskusi bagi siswa atau kelompok lain yang ingin menyanggah kelompok presenter. Guru berjalan berkeliling untuk memotivasi siswa dan melakukan pengamatan. Disamping itu juga membantu siswa yang mengalami kesulitan dalam memahami materi tersebut apabila masih belum mengerti penjelasan dari tutor.

Guru membahas bersama hasil kerja kelompok dan membuka kesempatan tanya jawab. Kegiatan tanya jawab ini dimanfaatkan oleh beberapa siswa yang masih belum mengerti tentang struktur kalimat. Presentasi berjalan cukup baik dan lancar. Setelah waktu yang diberikan untuk kegiatan tutorial berakhir, guru memberikan kesimpulan dan meminta siswa melanjutkan latihan soalnya untuk dikerjakan di rumah. Kemudian guru menutup pembelajaran dengan mengucapkan salam penutup. Kegiatan evaluasi berjalan baik. Hasil evaluasi langsung dikumpulkan begitu bel tanda pergantian jam pelajaran berbunyi.

Beberapa kendala yang ditemukan dari segi siswa sebagai berikut:

Presentasi masih kurang, guru sebaiknya memberikan masukan bagaimana berkomunikasi dengan baik dalam hal ini waktu presentasi jawaban soal di depan kelas; (2) Belum maksimalnya siswa dalam menggunakan waktu yang diberikan saat kegiatan tutorial. Hal ini dapat dilihat dari masih adanya beberapa siswa yang kurang aktif dan melakukan aktivitas lain selain diskusi tentang materi pelajaran; (3) Sulitnya berinteraksi antara anggota kelompok karena perbedaan dalam kemampuan akademisnya; (4) Kurangnya rasa tanggung jawab anggota kelompok, sehingga dalam kegiatan tutorial juga cenderung tidak mau tahu.

Beberapa kendala yang ditemukan dari segi guru sebagai berikut:

(1) Masih banyak siswa merasa segan bertanya langsung pada guru pada saat pembelajaran, mereka baru mau bertanya atau mengemukakan pendapat setelah ditunjuk langsung oleh guru. Mereka merasa lebih nyaman bertanya kepada guru apabila guru mendekati mereka (seperti pada saat monitoring); (2) Guru dalam menjelaskan materi dan memberikan contoh atau mendemonstrasikan pengerjaan soal terlalu cepat sehingga sulit untuk diikuti. Waktu yang disediakan guru untuk tanya jawab juga sangat terbatas, sehingga siswa merasa tidak ada kesempatan siswa untuk mengungkapkan permasalahannya tentang materi yang belum dipahami kepada guru; (3) Suara guru pada saat menjelaskan materi pembelajaran kurang keras sehingga siswa yang duduk di belakang tidak dapat mendengar penjelasan guru secara jelas; (4) Guru belum memberikan penghargaan kepada siswa yang mampu menyelesaikan tugas dengan benar, teliti, dan lebih cepat daripada siswa yang lain.

Solusi yang dilakukan guru untuk mengatasi kendala dari siswa yaitu: (1) Guru memberikan masukan bagaimana berkomunikasi dengan baik dalam hal ini waktu 
presentasi jawaban soal di depan kelas; (2) Guru memperhatikan siswa secara merata agar siswa yang kurang aktif merasa diperhatikan. (3) Guru menjembatani keterbatasan siswa. (4) Guru memberi pengertian tentang tanggung jawab anggota dalam kelompok.

Solusi yang dilakukan guru untuk mengatasi kendala dari guru yaitu: (1) Guru mendekati ke siswa agar bersedia bertanya atau menawarkan ke siswa untuk bertanya; (2) Guru membagi waktu dan menerapkannya dalam pembelajaran agar waktu yang digunakan untuk tanya jawab cukup longgar;

(3) Guru menjelaskan materi dengan memposisikan diri di tengah siswa; dapat memberi penghargaan kepada siswa.

(4) Guru menyiapkan hadiah ringan untuk

\section{SIMPULAN}

Dalam tahap perencanaan, terlebih dahulu guru membuat perencanaan pembelajaran yang berupa silabus, prota, promes, dan RPP. Silabus yang digunakan adalah dari Depdiknas, kemudian silabus tersebut ditelaah dan disesuaikan dengan kondisi sekolah. Silabus meliputi standar kompetensi, kompetensi dasar, materi pokok, kegiatan Pembelajaran, indikator, penilaian, alokasi waktu dan sumber bahan. Prota dan promes diperlukan untuk menentukan penetapan alokasi waktu agar seluruh kompetensi dasar yang ada dalam kurikulum seluruhnya dapat dicapai oleh murid. Guru dalam penyususnan RPP sudah baik, sudah mengacu pada silabus namun guru tidak membuatnya sendiri. RPP dibuat oleh Tim KKG.

Pelaksanaan Pembelajaran Struktur Kalimat dengan Model Tutor Sebaya di SDN Bendungan I Kecamatan Kedawung Kabupaten Sragen, guru mengawali pembelajaran dengan salam, melakukan presensi. Lalu guru memberikan motivasi sebelum memulai pelajaran. Dilanjutkan guru melakukan tanya jawab sebagai apersepsi. Siswa dikelompokkan kedalam 8 kelompok tiap kelompok empat siswa, dengan 1 siswa sebagai tutor atau ketua kelompok yang memiliki nilai prestasi belajar diatas rata-rata. Membagi siswa ke dalam kelompok tiap kelompok terdiri dari siswa yang berprestasi rendah, sedang, dan tinggi. Selama belajar dalam kelompok, tugas tutor dalam kelompok adalah menguasai materi pelajaran dan membantu teman satu kelompok untuk menguasai materi. Anggota kelompok yang mengalami kesulitan terlebih dahulu bertanya kepada teman sekelompok, tutor sebaya, dan apabila mengalami kesulitan baru bertanya kepada guru.

Guru membahas bersama hasil kerja kelompok dan membuka kesempatan tanya jawab. Kegiatan tanya jawab ini dimanfaatkan oleh beberapa siswa yang masih belum mengerti tentang struktur kalimat. Setelah waktu yang diberikan untuk kegiatan tutorial berakhir, guru memberikan kesimpulan dan meminta siswa melanjutkan latihan soalnya untuk dikerjakan di rumah. Kemudian guru menutup pembelajaran dengan mengucapkan salam penutup.

Kendala dalam Pembelajaran Struktur Kalimat dengan Model Tutor Sebaya di SDN Bendungan I Kecamatan Kedawung Kabupaten Sragen. Kendala dari siswa yaitu: (1) Presentasi masih kurang, guru sebaiknya memberikan masukan bagaimana berkomunikasi dengan baik dalam hal ini waktu presentasi jawaban soal di depan kelas; (2) Belum maksimalnya siswa dalam menggunakan waktu yang diberikan saat kegiatan tutorial. Hal ini dapat dilihat dari masih adanya beberapa siswa yang kurang aktif dan melakukan aktivitas lain selain diskusi tentang materi pelajaran; (3) Sulitnya berinteraksi antara anggota kelompok karena perbedaan dalam kemampuan akademisnya; (4) Kurangnya rasa tanggung jawab anggota kelompok, sehingga dalam kegiatan tutorial juga cenderung tidak mau tahu. 
Beberapa kendala yang ditemukan dari segi guru sebagai berikut:

(1) Masih banyak siswa merasa segan bertanya langsung pada guru pada saat pembelajaran, mereka baru mau bertanya atau mengemukakan pendapat setelah ditunjuk langsung oleh guru. Mereka merasa lebih nyaman bertanya kepada guru apabila guru mendekati mereka (seperti pada saat monitoring); (2) Guru dalam menjelaskan materi dan memberikan contoh atau mendemonstrasikan pengerjaan soal terlalu cepat sehingga sulit untuk diikuti. Waktu yang disediakan guru untuk tanya jawab juga sangat terbatas, sehingga siswa merasa tidak ada kesempatan siswa untuk mengungkapkan permasalahannya tentang materi yang belum dipahami kepada guru; (3) Suara guru pada saat menjelaskan materi pembelajaran kurang keras sehingga siswa yang duduk di belakang tidak dapat mendengar penjelasan guru secara jelas; (4) Guru belum memberikan penghargaan kepada siswa yang mampu menyelesaikan tugas dengan benar, teliti, dan lebih cepat daripada siswa yang lain.

Solusi yang dilakukan guru untuk mengatasi kendala dari siswa yaitu: (1) Guru memberikan masukan bagaimana berkomunikasi dengan baik dalam hal ini waktu presentasi jawaban soal di depan kelas; (2) Guru memperhatikan siswa secara merata agar siswa yang kurang aktif merasa diperhatikan. (3) Guru menjembatani keterbatasan siswa. (4) Guru memberi pengertian tentang tanggung jawab anggota dalam kelompok.

Solusi yang dilakukan guru untuk mengatasi kendala dari guru yaitu: (1) Guru mendekati ke siswa agar bersedia bertanya atau menawarkan ke siswa untuk bertanya; (2) Guru membagi waktu dan menerapkannya dalam pembelajaran agar waktu yang digunakan untuk tanya jawab cukup longgar; (3) Guru menjelaskan materi dengan memposisikan diri di tengah siswa;

(4) Guru menyiapkan hadiah ringan untuk dapat memberi penghargaan kepada siswa.

\section{PERSANTUNAN}

Disampaikan teerima kasih kepada; 1) Redaksi Jurnal Ilmiah Klitika yang telah mempublikasikan artikel ini; 2) Kepala Sekolah dan Guru Sekolah Dasar Negeri Bendungan I Kecamatan Kedawung Kabupaten Sragen yang telah bersedia sebagai tempat untuk diteliti.

\section{DAFTAR PUSTAKA}

Ahmadi, Abu \& Supriyono, Widodo. 2004. Psikologi Belajar. Jakarta: PT Rineka Cipta.

Nugrahani, Farida. 2010. Metodologi Penelitian Kualitatif: Teori dan Aplikasi. Surakarta: UNS Press.

Rusman, 2011. Model-Model Pembelajaran Mengembangkan Profesionalisme Guru. Jakarta: PT Rajagrafindo Persada.

Semiawan, Conny. 2000.Pendekatan Ketrampilan Proses. Jakarta: PT Gramedia.

Suherman. 2003. Faktor Kesulitan Belajar, Jakarta: Gramedia.

Sukmadinata, 2007. Landasan Psikologi Proses Pendidikan. Bandung: PT Remaja Rosdakarya. 
KLITIKA: Jurnal Ilmiah Pendidikan Bahasa dan Sastra

Indonesia. Volume 1, Nomor 2, 2019, pp 132 - 139
p-ISSN: 0000-0000

e-ISSN: 2714-9862 